\title{
VIRTUAL TOURISM EXHIBITION ACTIVITY IN ENGLISH FOR TOURISM CLASS: STUDENTS' PERSPECTIVES
}

\author{
${ }^{1}$ Suprayogi*, ${ }^{1}$ Budi Eko Pranoto \\ ${ }^{1}$ Universitas Teknokrat Indonesia, Indonesia \\ *Corresponding Author: suprayogi@teknokrat.ac.id
}

\begin{abstract}
As the need of the contextual learning for English for Tourism class increases, the new teaching methods with integration of technology need to be further explored. Recently, the common method used in the class usually focuses on monologue, lecture, video exploration and presentation, meanwhile, contextual simulation is rarely used and addressed. This study aims at observing the implementation of virtual tourism exhibition activity in English for Tourism class from the students' perspectives. Qualitative descriptive study was employed by selecting 56 students of English Literature major in $\mathrm{T}$ university as research subject. A questionnaire focusing on the area of learning objective, technology literacy and interaction was used to collect the necessary data. The result shows that virtual tourism exhibition has given them a learning alternative during COVID-19 quarantine, some improvement in speaking has been made, and the degree of technology literacy to conduct virtual learning was found to be satisfying. However, students still prefer having face-to-face activity to virtual meeting. Further, the interaction between students and lecturer is still covered despite of limited time and unstable internet connection. This study suggests that the analysis from the teacher perspective and quantitative calculation on students' performance in exhibition simulation should be further explored.
\end{abstract} Keywords: English for Tourism; Project Based Learning; Speaking; Tourism Exhibition;
Virtual Learning

\begin{abstract}
ABSTRAK
Seiring dengan semakin meningkatnya kebutuhan pembelajaran kontekstual di mata kuliah bahasa Inggris Kepariwisataan di tingkat Universitas, maka metode pembelajaran baru yang mengintegrasikan teknologi masih perlu dikembangkan lebih lanjut. Selama ini, metode pembelajaran yang dipakai pada kelas ini masih berfokus pada monolog, eksplorasi video dan presentasi, sementara itu pembelajran berbasis simulasi secara kontekstual jarang sekali mendapat perhatian. Penelitian ini sendiri mengkaji penerapan kegiatan pameran pariwisata berbasis virtual di dalam kelas bahasa Inggris Kepariwisataan dalam penelitian ini dilihat dari respon mahasiswa yang mengikuti kegiatan tersebut. Selanjutnya, penelitian ini sendiri merupakan penelitian kualitatif yang melibatkan sekitar 50 mahasiswa program studi Sastra Inggris di universitas $\mathrm{T}$. Kemudian, data diambil melalui kuesioner yang berfokus pada pendapat mahasiswa mengenai capaian pembelajaran, interaksi teknologi dan interaksi dalam pembelajaran. Hasil penelitian menunjukkan bahwa kegiatan pameran pariwisata virtual dapat menjadi alternatif selama COVID-19. Mahasiswa mengalami peningkatan di beberapa aspek dan literasi teknologi mahasiswa untuk melaksanakan pembelajaran virtual berada pada tingkat yang memuaskan. Namun demikian, mahasiswa masih memilih pembelajaran tatap muka dibandingkan dengan pembelajaran virtual. Interaksi dosen dan mahasiswa masih dapat dilaksanakan meskipun internet tidak stabil dan waktu pembelajaran yang singkat. Penelitian selanjutnya diharapkan dapat melihat penerapan pameran pariwisata ini dari perspektif pengajar dan dari efektifitas yang diukur secara kuantitatif.
\end{abstract}


Suprayogi, \& Pranoto, B.E. (2020). Virtual Tourism Exhibition Activity in English for Tourism Class: Students' Perspectives. Celtic: A Journal of Culture, English Language Teaching, Literature, \& Linguistics, 7(2), 199-207.

Kata Kunci: Bahasa Inggris Kepariwisataan; Pameran Pariwisata Virtual; Pandangan Mahasiswa; Pembelajaran di Masa COVID-19; Pembelajaran Virtual

\section{INTRODUCTION}

The role of English for global communication is more highlighted in the era of Industrial Revolution 4.0 as English is not only functioned as language for technology but also as language for cross-cultural communication. Even now, English is seen as a global commodity for its global influence of the speakers (Bouton, 2017). Therefore, English is seen an asset both for the learners and the teachers (Suprayogi \& Pranoto, 2020) that should be mastered for education purposes as well as for cross border trip such as business and tourism. In Indonesian context, by the development of tourism sector, the role of English gains higher attention. English is one of the skills that should be further developed to advance the tourism in Indonesia (International Labour Organization, 2009). Therefore, the development of tourism in Indonesia should be followed by the development of tourism competences, one of which is English for the tourism practitioners.

Many English literature major graduates in Indonesia work in tourism sector as they do not only study the literature competences but also English for Specific Purposes (ESP) competences, especially English for tourism. ESP is learning English as the second language so that the learners can master specific field depending on the needs of the learner (Hutchinson \& Waters, 1987). What makes it different from general English is that ESP highlights the variety of materials (Pranoto \& Suprayogi, 2020). The contribution of English literature graduate is seen as a response of high demand of tourism practitioner that should be able to speak English. Commonly, English for Tourism covers the conversation in hotel, tour, and exhibition setting and the presentation on tourism events and potentials.

In the context English literature of $\mathrm{T}$ university (initial name), English for Tourism is a compulsory subject taught in the second semester where it is expected that the students are exposed to many setting on tourism conversation as needed in the future job. However, based on the preliminary observation of English for Tourism in the academic year of 2018/2019 by the researcher, it is found that the learning process still concerns on group presentation on the description of tourism events and activities. The researcher believes that the ideal learning process in this class should also focuses on contextual teaching and learning (CTL), that is the concept helping the teacher to connect learning material and the real world (Sears, 2003). Therefore, the teaching method should always be further explored to meet this need.

One of the authentic tourism activities possible to be adapted in the course of English for Tourism is tourism exhibition simulation. In the exhibition, there are text info, narration, and interactivity (Ahlamo, 2013). In international tourism exhibition, there are significant interaction between exhibitor and visitor using English where the exhibitor should explain tourism information confidently and attractively. In practical context, tourism exhibition is held to increase tourism branding and selling. It also connects the tourism industry and the potential target market (Yego, 2015). In other words, exhibition provides multiple opportunities for learning English contextually.

For the past few years, researches on English for Tourism (ET) as ESP have been conducted. The research from (Sari, 2016) focuses on ET material development 
based on local content meanwhile (Puspitasari, 2018) developed the content of ET based on Stakeholders' need. In terms of method for teaching ET, Olivia \& Pakpahan (2018) haved used monologue in teaching meanwhile Marzá (2014) employed corpusbased approach to teaching ET. The scope of investigation of these research mainly focuses on content design and method; however, rarely investigate the teaching methods fitting the current contextual need and technological trend such as the use of synchronous learning or video conference.

During COVID-19 pandemic, offline learning process is not possible to be conducted as instructed by Ministry of National education. Moreover, tourism exhibition simulation activity requires crowd to build the learning ambience, therefore, it is worrying that it can spread the virus. As the alternative, online tourism exhibition simulation activity is proposed. This study focuses at revealing the students' voice on the implementation of virtual tourism exhibition activity in English for Tourism courses in an Indonesian tertiary education. This study answers the research question "how are students' the perception towards tourism exhibition activity in English for Tourism class?". Furthermore, this study fills the gap of previous studies in English for Tourism, which mostly focused on

\section{METHOD}

This study employs qualitative descriptive methods. This method highlights diverse points of view of analysis, and also concerns on inductive and deductive processes (Creswell, 2014). This method is selected to explore the oral and written data that describe the research object. The subject of this study is 56 students of English literature study program batch 2019 of T university.

These students enrolled in English for Tourism or Interactional Conversation course. Tourism exhibition activity is conducted in the week 15 as an integrated review activity of cuisine, art, tourism event, tour guide topic. The exhibition is conducted virtually using zoom or WhatsApp depending on the feature that fit students condition during COVID-19 study from home activity. As successful projects require both in-class and out-of-class preparation (Burston, 2005) they were given one week to prepare the materials and rehearse the exhibition.

Data were collected through google form online questionnaire addressing the students' voice after completing the activity of tourism exhibition. The questionnaire consisting of 15 item where positive and negative statements are distributed evenly. The statements contain the idea usefulness, practicality, technology adaptation, interaction and impact of news voice over activity which should be responded by the students using Likert scale of strongly agree, agree, disagree, and strongly disagree. The questionnaire was distributed in the meeting 16 . The responses were then analyzed to see whether students have good perspective or not toward the activity of news voice over. Riduwan's (2008 in Mulya Sari, 2018) interpretation on likert scale's result was adopted stating that the result is considered very significant when reaching $81-100 \%$, significant if in the range of $61-80 \%$, insignificant if in the range of in $41-60 \%$, and very insignificant if in the range of $0-20 \%$. 
Suprayogi, \& Pranoto, B.E. (2020). Virtual Tourism Exhibition Activity in English for Tourism Class: Students' Perspectives. Celtic: A Journal of Culture, English Language Teaching, Literature, \& Linguistics, 7(2), 199-207.

\section{FINDINGS}

This study focuses on the implementation of tourism exhibition activity from the voice of students. The finding of this study is integrated with discussion and presented in three sub discussions, which are achieving learning objective, technology literacy and interaction. The tables below apply term SA to indicate strongly agree, $\mathrm{A}=$ agree, $\mathrm{D}=$ disagree, and $\mathrm{SD}=$ strongly disagree.

To see whether virtual tourism exhibition is a good method to use in English for Tourism course, it is important to see the concept of ideal learning from the perspective of the students. Then, the outcomes are further revealed. The following summary is presented to answer these two concerns.

Table 1. Students' Voice on Ideal Learning and the outcomes of Tourism Exhibition

\begin{tabular}{lcccc}
\hline \multicolumn{1}{c}{ Statement } & $\mathrm{SA}$ & $\mathrm{A}$ & $\mathrm{D}$ & $\mathrm{SD}$ \\
\hline $\begin{array}{l}\text { In learning Transactional conversation (English for } \\
\text { tourism), it is important to know about contextual }\end{array}$ & $41.1 \%$ & $58.9 \%$ & $0 \%$ & $0 \%$ \\
vocabulary and phrases & & & \\
$\begin{array}{l}\text { I prefer two ways communication (question and } \\
\text { answer) in practicing English for tourism }\end{array}$ & $21.4 \%$ & $75 \%$ & $3.6 \%$ & $0 \%$ \\
$\begin{array}{l}\text { I love doing role play of becoming exhibitor rather } \\
\text { than doing in class slide presentation }\end{array}$ & $16.1 \%$ & $67.8 \%$ & $16.1 \%$ & $0 \%$ \\
$\begin{array}{l}\text { The atmosphere and ornament of exhibition that I } \\
\text { made and decorate doesn't affect me to feel the real } \\
\text { experience of becoming the exhibitor/tour guide }\end{array}$ & $16.1 \%$ & $44.6 \%$ & $39.3 \%$ & $0 \%$ \\
$\begin{array}{l}\text { I think in this exhibition activity, my English fluency } \\
\text { has not improved }\end{array}$ & $5.4 \%$ & $46.4 \%$ & $46.4 \%$ & $1.8 \%$ \\
$\begin{array}{l}\text { I don't see my improvement on mastery on region's } \\
\text { tourism potential in this exhibition project. }\end{array}$ & $3.6 \%$ & $26.8 \%$ & $67.8 \%$ & $1.8 \%$ \\
\hline
\end{tabular}

Due to COVID 19 pandemic, there are several adjustments made to complete the course of English for Tourism. In the previous year, students of English literature study program of Universitas Teknokrat Indonesia are exposed to face to face group exhibition, meawhile for 2019/2020 academic year, the exhibition is conducted offline and individually through video conference platform. Therefore, the students' voice maybe different.

Table 2. Students' Voice on Technology Adaptation

\begin{tabular}{lcccc}
\hline \multicolumn{1}{c}{ Statement } & SA & A & D & SD \\
\hline $\begin{array}{l}\text { I think it is more convenient to conduct exhibition } \\
\text { virtually compared to offline exhibition }\end{array}$ & $3.6 \%$ & $51.8 \%$ & $41.1 \%$ & $3.6 \%$ \\
$\begin{array}{l}\text { Selected video conference platform offered by my } \\
\text { lecturer (some class use zoom, some class use }\end{array}$ & $8.9 \%$ & $80.4 \%$ & $8.9 \%$ & $1.8 \%$ \\
$\begin{array}{l}\text { WhatsApp) in the last exhibition fit my internet } \\
\text { quality }\end{array}$ & & & \\
$\begin{array}{l}\text { I found difficulties in setting the booth, recording and } \\
\text { video conference well }\end{array}$ & $7.1 \%$ & $60.7 \%$ & $32.1 \%$ & $0 \%$ \\
$\begin{array}{l}\text { If in the future I have typical task in having virtual } \\
\text { exhibition, I cannot handle it myself }\end{array}$ & $3.6 \%$ & $28.6 \%$ & $67.9 \%$ & $0 \%$ \\
\hline
\end{tabular}

During the virtual class or remote learning for the topic of exhibition, the coordination is all conducted via zoom and whatsapp. Interaction aspect in the process 
Celtic: A Journal of Culture, English Language Teaching, Literature and Linguistics

Vol. 7, No. 2, December 2020.

E-ISSN: 2621-9158 P-ISSN:2356-0401

http://ejournal.umm.ac.id/index.php/celtic/index

of virtual tourism exhibition becomes an important point to discuss. The following table reflects the result of students' voice in the aspect of interaction.

Table 3. Students' Voice on Interaction

\begin{tabular}{lcccc}
\hline \multicolumn{1}{c}{ Statement } & SA & A & D & SD \\
\hline $\begin{array}{l}\text { I don't have good interaction between the lecturer } \\
\text { and I to get the feedback }\end{array}$ & $3.6 \%$ & $25 \%$ & $66.1 \%$ & $5.4 \%$ \\
$\begin{array}{l}\text { I can deliver question and ask for feedback to my } \\
\text { classmate }\end{array}$ & $14.3 \%$ & $80.4 \%$ & $5.4 \%$ & $0 \%$ \\
$\begin{array}{l}\text { The exhibition booth of my friends seen in video } \\
\text { conference doesn't inspire me to improve my booth }\end{array}$ & $1.8 \%$ & $32.1 \%$ & $62.5 \%$ & $3.6 \%$ \\
$\begin{array}{l}\text { By having Q and A using video conference, I see my } \\
\text { confidence improved }\end{array}$ & $8.9 \%$ & $87.5 \%$ & $3.6 \%$ & $0 \%$ \\
\hline
\end{tabular}

DISCUSSION

\section{On Ideal Learning and Tourism Exhibition Learning Outcome}

The table 1 shows that there are $41.1 \%$ students strongly agree and $58.9 \%$ agree that "it is important to know contextual vocabulary and phrases in English for tourism class". This means that all students have strong foundation of the language aspect the students need to master. Contextual vocabulary and phrases are important as the materials of English for Tourism are really specific. Limitation of vocabulary especially in second language will impede successful communication (Alqahtani, 2015). Furthermore, students also prefer two way communications during the class session (21.4\% strongly agree, $75 \%$ agree). Students already aware that two-way communication practice expose them to various feedbacks, context, and language feature exchanged from lecturer and students. Students could also get chances to ask question which results in the improvement of their class participation (Rido, 2019). This further eases them to meet different kinds of situation and client in their future job.

When it comes to student-centered activity and two ways communication activity, role play is more preferred than presentation, with $16.1 \%$ strongly agree and $67.9 \%$ agree Most of them considered that role play activity a fun learning process because they are placed in various settings are trained to solve certain cases. In nature, role play for college students is suitable as it gives indirect experience, and encourages them to interact and directly practice their English (Krebt, 2017). In addition, role play activity enables them to experience world of customer relation and tour guiding. On the other hand, class presentation for them is considered formal and has less intensity to interact, which is only in question and answer session. These creative activities initiated by the lecturers is the spirit of ESP, in which according to Masyhud (2018) the teacher should provide variety of interesting materials in a conducive learning atmosphere.

In the exhibition, students were asked to create tourism booth by themselves and for themselves using the properties they can find around. They were given opportunity to explore and design booth at home expecting that they can feel the real exhibition. However, the questionnaire result shows that $16.1 \%$ of them strongly agree and $44.6 \%$ agree that the atmosphere and ornament of exhibition that they made and decorate doesn't affect them to feel the real experience of becoming the exhibitor/tour guide, meanwhile $39.3 \%$ disagree. These data can be interpreted in several ways. First, the decoration of the virtual exhibition doesn't resemble the real or offline exhibition. In this context, we don't push them to spend much budget to decorate, rather they can 
create using used property. Second, the exhibition is conducted online, so in students' place, only student him/herself. It probably makes them lost the ambiance and difficult to see the decoration of their peer.

In term of students' fluency improvement, the result is intriguing in which there is a trend of almost balance answer from the students. There are $51.8 \%$ students stated that their fluency has improved meanwhile $48.2 \%$ stated has not. Those who feel improved are probably because they can maximize the rehearsal and preparation team, which is one week. They may feel easier to speak because the picture, ornament, and small information paper are there used to connect one idea to another. For those who feel not improved, the students may still have not not enough preparation with a new area to be explored as a content. It is because from one student to another, they have different time preparation. However, the mastery on tourism potential contents is significant for the students. It is stated that $69.7 \%$ feel that they are improved in terms of the mastery on region's tourism potential in this exhibition project. The students are required to collect and deliver information as tourism exhibitor about the basic description and uniqueness of the tourism aspect.

\section{On Technology Adaptation during remote learning}

Table 2 shows that more than half of the students (55.4\%) prefer offline exhibition to virtual exhibition. In the offline exhibition, they are expected to meet lots of guest from lecturers, other students as well as visitors from public, so they may feel the exhibition livelier; however, in virtual exhibition they only communicate with classmates with limited time. Furthermore, in the implementation of tourism exhibition, students are given the choice of which platform can accommodate their needs according to internet signal coverage. Some of them use WhatsApp video call, especially those who live far away from Bandarlampung city, and others use Zoom. The result shows that $8.9 \%$ strongly agree and $80.4 \%$ agree that the platform they chose fit their internet quality. It is important to know students' internet capacity and outreach before implementing internet based activity. Furthermore, in the context of rural area, not many students can afford good internet signal where some of them should go to nearest internet provider tower, electricity, or higher land. The reflection of students' choice in this research shows win-win solution from the side of lecturer as well as students to reach learning objective.

In terms of students' ability to set up the booth, record the video and connect the video to other participant are also concerned. There are $67.8 \%$ of the students didn't find difficulty to make it, meanwhile $32.2 \%$ did. In addition, in terms of their individual skills, $67.9 \%$ are able to do the same thing in the future. It means that the students already have to use technology in their learning, especially video conference and recording feature. In other class, these students use learning management system (LMS) in their campus and usually ask to have recorded presentation. Outside the class, they are active in social media and other internet platform. However, the rest of the students $(32.1 \%)$ are those who face the challenges in setting up the video for the conference. In this research context, some of the students are in remote areas and are not equipped with laptop. Therefore, the conference setting was hindered. 


\section{On Classroom interaction}

The tourism exhibition in this context consists of three main activities namely preparation, exhibition and evaluation. In the preparation stage, students were having rehearsal of exhibition where they prepare the booth and the content as well. Video conference enable lecturer and students establish interaction during the process. There are $70.5 \%$ students who feel that they have a good interaction with the lecturer and they get feedback too. It can be inferred that the interaction ran well in the learning process and they have received feedback from the performance preparation. It is in the same vein, (Klimova, 2015) believes that feedback can make the students aware of their strength and weaknesses, and motivated to improve their performance.

Interaction among students in this research is perceived positively. They feel that they were given chances to discuss and comment on their classmate's exhibition and speaking performance. This peer feedback is proven effective in speaking class (Wenny J \& Fajar, 2019) and provides meaningful learning opportunity and complements teacher's feedback as stated by Saito (2013). One of the feedback content is students' language error. When students perform language error, it can be cultivated further by the teacher to find out anticipated teaching strategies (Puspita, 2019) and also can be the peer example for other students. This is in line with the result of next concern that having question and answer session in the preparation process help them to improve their confidence. It can be interpreted in several ways. Having good interaction in terms of giving-receiving feedback and asking question possibly making them motivated to speak up because they finally know what areas they need to improve; therefore, they feel confidence in the delivery.

\section{CONCLUSION}

Students see tourism exhibition activity as an interesting and useful activity for them in English for tourism class as it provides room for practicing exploring real life context. It also enables the students to have interaction from the preparation until the simulation day. However, it should be highlighted that for the students, tourism exhibition activity improves their confidence in role-playing and understanding on the material, but it does not make them more fluent in delivery. Furthermore, when conducted online, students feel that they are independent and literate enough to use video conference application. However, they partially lost the exhibition ambience making half of them still prefer offline exhibition. Further research could investigate how the English vocabulary of tourism is learned and used during the exhibition

\section{ACKNOWLEDGMENT}

The research is fully supported by Ministry of Research and Technology/ National Research and Innovation Board Republic of Indonesia under Penelitian Dosen Pemula scheme 2020.

\section{REFERENCES}

Ahlamo, E. (2013). The Use of Interactivity in Educational Exhibitions (Tampere
University of Applied Science). A Retrieved
https://www.theseus.fi/bitstream/handle/10024/57802/Ahlamo_Eeva-
Kaisa.pdf? sequence $=1$


Suprayogi, \& Pranoto, B.E. (2020). Virtual Tourism Exhibition Activity in English for Tourism Class: Students' Perspectives. Celtic: A Journal of Culture, English Language Teaching, Literature, \& Linguistics, 7(2), 199-207.

Alqahtani, M. (2015). The importance of vocabulary in language learning and how to be taught. International Journal of Teaching and Education, III(3), 21-34. https://doi.org/10.20472/te.2015.3.3.002

Bouton, K. (2017). English as a Global Commodity. Liberty University.

Burston, J. (2005). Video Dubbing Projects in the Foreign Language Curriculum. CALICO Journal, 23(1), 79-92. https://doi.org/10.1558/cj.v23i1.79-92

Creswell, J. W. (2014). Research Design: Qualitative, Quantitative, and Mixed Methods Approache. California: SAGE Publication.

Hutchinson, T., \& Waters, A. (1987). English for Specific Purposes: A learning-centred approach. Cambridge: Cambridge University Press.

International Labour Organization. (2009). Implications of the Global Economic Crisis for Tourism Employment: Case Study For Indonesia. Retrieved from https://www.ilo.org/wcmsp5/groups/public/---asia/---ro-bangkok/---ilojakarta/documents/publication/wcms 122154.pdf

Klimova, B. (2015). The Role of Feedback in EFL Classes. Procedia - Social and Behavioral Sciences, 199, 172-177. https://doi.org/10.1016/j.sbspro.2015.07.502

Krebt, D. M. (2017). The Effectiveness of Role Play Techniques in Teaching Speaking for EFL College Students. Journal of Language Teaching and Research, 8(5), 863. https://doi.org/10.17507/jltr.0805.04

Marzá, N. E. (2014). A practical corpus-based approach to teaching English for tourism. International Journal of Applied Linguistics and English Literature, 3(1), 129136. https://doi.org/10.7575/aiac.ijalel.v.3n.1p.129

Masyhud, M. (2018). Promoting Lesson Study At English for Specific Purposes (Esp): Teacher'S Best Practice Context. Celtic: A Journal of Culture English Language $\begin{array}{llll}\text { Teaching Literature } \& \text { Linguistics, } & 5(2), & 36 .\end{array}$ https://doi.org/10.22219/celticumm.vol5.no2.36-44

Mulya Sari, F. (2018). Undergraduate Students' Attitudes To the Implementation of Whatsapp Group As Their Learning Media in the Efl Classroom. Researchgate.Net, (November 2018), 0-8. Retrieved from https://www.researchgate.net/publication/335320213

Olivia, R., \& Pakpahan, A. (2018). Improving Speaking Skill of Tourism Vocational High School Students Through Project Based Learning. RETAIN, 6, 44-51.

Pranoto, B. E., \& Suprayogi, S. (2020). A Need Analysis of ESP for Physical Education. Premise: Journal of English Education and Applied Linguistics, 9(1), 94-110.

Puspita, D. (2019). Error Analysis on Learners' Interlanguage and Intralanguage: A Case Study of Two Adolescent Students. Teknosastik, 17(2), 12. https://doi.org/10.33365/ts.v17i2.321

Puspitasari, I. (2018). Developing English for Tourism Materials Trough Stakeholders Needs Analysis. English Review: Journal of English Education, 7(1), 147. https://doi.org/10.25134/erjee.v7i1.1534

Rido, A. (2019). What is newton's law of inertia ?: The Use of Questions in Science Lectures. $\quad$ LITERA, 18(2), 312-325. https://doi.org/https://doi.org/10.21831/1tr.v18i2.21948

Saito, Y. (2013). The Value of Peer Feedback in English Discussion Classes. In N. Sonda \& A. Krause (Eds.), JALT 2012 Conference Proceedings (pp. 430-438). 
Celtic: A Journal of Culture, English Language Teaching, Literature and Linguistics

Vol. 7, No. 2, December 2020.

E-ISSN: 2621-9158 P-ISSN:2356-0401

http://ejournal.umm.ac.id/index.php/celtic/index

Retrieved from https://jalt-publications.org/files/pdf-article/jalt2012-045.pdf

Sari, R. A. (2016). Teaching English for Tourism in Bali Based on Local Culture: What Do Students Need? The 4th International Seminar on English Language \& Teaching (ISELT), 221-229. Retrieved from http://ejournal.unp.ac.id/index.php/selt/issue/view/754

Sears, S. (2003). Introduction to Contextual Teaching and Learning (D. R. Walling, Ed.). Indiana: Phi Delta Kappa.

Suprayogi, S., \& Pranoto, B. E. (2020). Students' Perspectives Toward News Voiceover Activity in Pronunciation Class. Proceedings of the Twelfth Conference on Applied Linguistics (CONAPLIN 2019), 430, 203-206. https://doi.org/10.2991/assehr.k.200406.041

Wenny J, S., \& Fajar, R. (2019). the Effect of Peer Assessment Towards Students' Speaking Skill At Semester II of STIE Muhammadiyah Jambi 2018-2019. Celtic: A Journal of Culture, English Language Teaching, Literature and Linguistics, 6(2), 26. https://doi.org/10.22219/celtic.v6i2.9886

Yego, S. J. (2015). the Role of Conferences, Meetings and Exhibitions in Promoting International Business in the Ministry of East Africa Affairs Commerce and Tourism in Kenya. Retrieved from http://erepository.uonbi.ac.ke/bitstream/handle/11295/93209/Yego_The role of conferences, meetings and exhibitions in promoting international business in the ministry of East Africa affairs commerce and tourism in Kenya.pdf?isAllowed $=y \&$ sequence $=1$ 